\title{
An Eagle Eye View of Mergers and Acquisitions: A recipe for venture expansion
}

\section{Abdulwaheed Dauda*}

Department of Entrepreneurship \& Bus Studies, Federal University of Technology, Minna, Nigeria

\begin{abstract}
In today's global, competitive environment, mergers and acquisitions are sometimes the only means for long-term survival and growth of firms. The underlying principle behind M\&A is simply $2+2=5$, when we merge two companies; the synergy produces the additional value of 5 . It is imperative that everyone involved in the process has a detail understanding of how the process works. An appropriate valuation method must be adopted to ascertain the worth of the companies in order to know whether the deal will be beneficial for the business concern. Merger and Acquisition especially in the banking sector is now a global phenomenon, the last few years has witnessed the creation of the world's banking groups through M \& A. All over the world and given the internationalization of finance, size has become an important ingredient for success in the globalizing world. The option of consolidation is predicated on the relationship between the two banks that are merging, the benefits accruing there-from involves creation of synergies and economies of scale, expanding operations and cutting costs. However, to ensure that the synergy envisage is fully harnessed, and to mitigate post-consolidation conflicts, adequate steps should be taken to train and retrain the staff of all the banks that have scaled the capitalization huddle while the regulatory environment has to be tightened to close all the loopholes that could come up as a result of the increased size of the firms in the industry.
\end{abstract}

Keywords: Valuation; Synergy; Target company; Due diligence; Consolidation; Merger; Acquisition

\section{Introduction}

Mergers and Acquisitions have become a big part of the corporate world, and are among the most strategic and tactical decisions made by companies. Wall Street investment bankers arrange many M\&A transactions everyday, which bring separate companies together to form larger ones.

Throughout the last decade, M\&A deals have been increasing significantly, while making some scenic news. M\&A deals can be worth hundreds of millions, or even billions, of dollars, and may dictate the fortunes of the companies involved for years to come. The future of a company, the career of a CEO, or the value of shareholders shares might be drastically changed. Therefore, any M\&A would significantly affect the daily running of the involved companies. With the current trends of globalization, more and more M\&A happened also internationally. Compared to national M\&A, international transactions are dealing with more complicated situations, such as culture differences, trading barriers, different national policies, etc.

The main idea of M\&A is $1+1=3$. To achieve this particular goal, both companies have to be valuated in details before merging. This brings the knowledge if the whole process of M\&A is able to be successfully finished, and how high can be expected profit after connection. The world over, strategic financing and investment decisions of corporate firms have also identified M\&A as one veritable route to business frontiers expansion. In Nigeria, a major wave in M\&A was experienced following the consolidation and recapitalization exercise in the banking sub sector. The underlying principle behind a Merger or Acquisition is to create shareholders value over and above that of the sum of the two companies.

\section{Review of Literature}

\section{Background of bank consolidation}

The Pan Reference Books Dictionary of Economics defined consolidation as the action of reinvesting a capital gain made on a speculative share in a more conservative security. The term could also connote the selling of equities at a gain and reinvesting of the proceeds in fixed-interest securities. Similarly, the Harold Sloan and Arnold Zurcher Dictionary of Economics (1970) conceptualized consolidation as a fusion of the assets and liabilities, in whole or in part, of two or more business establishments to form an entirely new establishment. From the above definitions, consolidation represents the idea of investment and the coming together of firms or enterprises as a single entity.

Consolidation also means larger sizes, larger shareholder bases and larger number of depositors. According to Adam [1], bank or corporate consolidation could be achieved by way of mergers and/or acquisition, recapitalization and proactive regulation. Bank consolidation is more than mere shrinking of the number of banks in any banking industry. It is expected to enhance synergy, improve efficiency, induce investor focus and trigger productivity and welfare gains Nnanna [2]. The main motivation behind consolidation is to maximize shareholders' value. Value may be maximized through Mergers and Acquisitions mainly by increasing the participating firm's market power in setting prices or by improving their efficiency and, in some cases, by increasing their access to the safety net. Imala [3] identified eight reasons for M\&A's in the financial services sector. They include:

- Cost savings, attributable to economics of scale as well as more efficient allocation of resources.

*Corresponding author: Abdulwaheed Dauda, Department of Entrepreneurship \& Bus Studies, Federal University of Technology, Minna, Nigeria. E-mail: dauda.abdulwaheed@futminna.edu.ng

Received December 01, 2012; Accepted December 02, 2012; Published March 10,2013

Citation: Dauda A (2013) An Eagle Eye View of Mergers and Acquisitions: A recipe for venture expansion. J Entrepren Organiz Manag 2: 102. doi:10.4172/2169026X.1000102

Copyright: (c) 2013 Dauda A. This is an open-access article distributed under the terms of the Creative Commons Attribution License, which permits unrestricted use, distribution, and reproduction in any medium, provided the original author and source are credited. 
- Revenue enhancement, resulting from the impact of consolidation on bank size, scope, and overall market power.

- Risk reduction, due to change in organizational focus and efficient organizational structure.

- New developments, which impose high fixed costs and the need to spread these costs across a large customer base.

- The advent of deregulation, which removed many important legal and regulatory barriers.

- Globalization, which engender a more globally integrated financial services industry and facilitated the provision of wholesale financial services and geographical expansion of banking operations.

- Financial stability, characterized by the smooth functioning of various components of the financial system, with each component resilient to shock.

- Shareholders' pressure on management to improve profit margins and returns on investment, made possible by new and powerful shareholder blocks.

The most important synergies to be derived through consolidation of firms in an industry are the ability to enjoy economies of scale, ability to earn increased revenue and the potentials for tax gains. These sources of synergy are discussed briefly hereunder:

Economies of Scale: One of the major advantages of the banking sector consolidation that is often harped on is its potential for firms in the industry to enjoy economies of scale. In his maiden address to the Bankers' Committee, the CBN Governor, Prof. Charles Soludo, posited that most banks in Nigeria have a capital base of less than US $\$ 10$ million or about N1.3billion and that the largest bank in Nigeria has a capital base of about US $\$ 298$ million compared to US $\$ 526$ million for the smallest bank in Malaysia. Without being dragged into the controversy of the choice of $\mathrm{N} 25$ billion as the benchmark for the capitalization of banks or the appropriateness of the comparison between Nigeria and Malaysia, one obvious fact is that the small size of Nigerian banks, each with expansive headquarters, separate investments in software and hardware, coupled with the bunching of branches in a few commercial centers, resulted in heavy fixed costs and operating expenses, thereby giving rise to very high average cost for the industry. Another issue related to the small size of Nigerian banks is the high cost of intermediation epitomized by the wide spread between deposit and lending rates. It would be recalled that the desire of the government to have a single digit lending rate has remained a mirage due, mainly, to the high cost of intermediation.

Globally, size has become an ingredient for success. An enhanced capital-base, all things being equal, is expected to confer competitive edge on a bank. It would enable the bank acquire relevant technology, engage high quality personnel and absorb shock. It would also position the bank to offer better and value-added services while increasing its earning capacity. Furthermore, consolidation increases the potential of banks to compete effectively at the national, regional and global levels.

Revenue Enhancement: One of the important reasons for mergers and acquisitions is the ability of combined firms to earn more revenue than two separate firms. Improved revenue may come from marketing gains, strategic benefits and market power. For instance, instead of advertising separately, the consolidated firm pulls its resources together to market the products and services of the firm, thereby reducing the unit cost of production.
Tax Gains: This may be a powerful incentive for mergers and acquisition. The increased size of a firm resulting from consolidation enables it enjoy tax gains resulting from the use of tax losses which would have resulted from separate net operating losses, the use of unused debt capacity and the use of surplus funds which the individual small companies were not able to invest.

However, having outlined the advantages of consolidation, it is important to note that in spite of the points adduced in favour of economies of scale as an advantage of consolidation, banking and finance literature have amply documented the fact that diseconomies of scale are possible. In fact, some studies have shown that the extent of economies of scale reported in the earlier studies was exaggerated and there exist diseconomies of scale in the large banks. However, a more recent study, Lemo [4] explains that in spite of observation of diseconomies of scale, there has been an underlying change in bank technology that has increased the minimum efficient size as well as favored large banks to small ones. From the foregoing, it is obvious that with the advancement in technology, consolidation would remain a preferred option for cost effectiveness and business growth.

\section{Valuation tools in Mergers \& Acquisitions}

Investors in a company that is aiming to acquire another one must determine whether the purchase will be beneficial to them. In order to do so, they must ask themselves how much the target company being acquired is really worth.

Naturally, both sides of the M\&A deal will have varied ideas about the worth of a target company: its promoters/seller will tend to value the firm high and above its worth while the buyer will try to get the lowest price possible to guarantee a higher return. The Deal makers employ a variety of methods and tools when assessing the worth of a target company. These involve:

(a) Comparative ratios: the following are two examples of the many comparative metrics on which acquiring firm may base their offers:

$\checkmark \quad$ Price Earnings Ratios (P/E Ratio): - with the use of this ratio for measurement, an acquiring company makes an offer that is a multiple of the earnings of the target firm. A cursory look at the P/E for all the stocks within the same industry group will give the acquiring company good guidance for what the targets' $\mathrm{P} / \mathrm{E}$ multiple should be.

$\checkmark \quad$ Enterprise Value-to-sales ratio (EV/Sales): - with this ratio of assessment, the acquiring company makes an offer as a multiple of the incomes while being conscious of the price-to-sales ratio of other companies in the industry.

(b) Replacement cost: - in a few cases, acquisition of companies are based on the cost of replacing the target company. The procedure of setting up a price would be inappropriate in a service industry where the key assets- people and ideas are difficult to value and establish.

(c) Discounted cash flow (DCF): -A key value tool in Merger \& Acquisition is discounted cash flow analysis which establishes a company's value consistent with its estimated future cash flows. Forecasted free cash flows (operating profit + depreciation + amortization of goodwill - capital expenditures - taxes - change in working capital) are discounted to a present value using the firm's weighted average cost of capital (WACC).

\section{Due Diligence}

There is a common trend that runs throughout much of the M \& 
A Process. It is called Due Diligence. Due diligence is a careful and extensive evaluation of the proposed merger, Maddigan [5]. A crucial poser is - Will this merger work? In order to answer this question, we must establish what kind of "fit" exists between the two companies. This includes:

\section{Investment fit}

What amount of financial resources will be required, what level of risk fits with the new organization etc?

\section{Strategic fit}

What level of management strengths are brought together through this $\mathrm{M} \& \mathrm{~A}$ ? Both sides must bring something unique to the table to create synergies.

\section{Marketing fit}

How will products and services complement one another between the two companies? How well do various components of marketing fit together - promotion programs, brand names, distribution channels, customer mix, etc?

\section{Operating fit}

How well do the various business units and production facilities fit together? How do operating elements fit together - labor force, technologies, production capacities, etc?

\section{Management fit}

The nature of expertise and talents do both companies bring to the merger? How well do these elements fit together - leadership styles, strategic thinking, ability to change, etc?

\section{Financial fit}

How well do financial elements of the companies fit together - sales, profitability, return on capital, cash flow, etc?

Due diligence is also very broad and deep, extending well beyond the functional areas (finance, production, human resources, etc.). This is very important since due diligence must expose all of the major risk associated with the proposed merger. In the view of Uwaleke [6] some of the risk areas that need to be investigated are:

- Market - How large is the target's market? Is it growing? What are the major threats? Can we improve it through a merger?

- Customer - Who are the customers? Does our business compliment the target's customers? Can we furnish these customers new services or products?

- Competition - Who competes with the target company? What are the barriers to competition? How will a merger change the competitive environment?

- Legal - What legal issues can we expect due to an M \& A? What liabilities, lawsuits, and other claims are outstanding against the Target Company?

Another reason why due diligence must be broad and deep is because management is depending on the creation of synergy values. Much of Phase I Due Diligence is concentrated on trying to specify and confirm the existence of synergies between the two companies. Management must know if their hope over synergies is real or false and about how much synergy can we expect? The total value assigned to the synergies give management some impression of how much of a premium they should pay above the valuation of the Target Company. In some cases, the merger may be called off because due diligence has revealed substantially less synergies than what management expected.

\section{Trend in Bank Consolidation}

The banking system consolidation is a global phenomenon, which started in the advanced economies. Two notable examples of countries experiencing a wave of mergers and consolidation in the banking industry in recent times are the United States of America (USA) and Japan, Hall [7]. According to Kwan [8], since the enactment of the Riegle-Neal Act, which allows interstate branch banking beginning from 1997, the number of large bank mergers in the USA has increased significantly. Today, the U.S. banking sector is reported to be in good shape, with record profits and relatively low volumes of problem loans. Further research on mega mergers in the USA suggests that merged banks experienced higher profit efficiency from increased revenues than did a group of individual banks, due to the fact that they provide customers with high value added products and services, Akhavin [9]. Furthermore, consolidation may allow a mega bank to enjoy a hidden subsidy which Kwan [8] referred to as "too-big to-fail" subsidy due to the market's perception of an illusion of government backing of a mega bank in times of crisis. The Japanese experience also shows that the consensus has been that significant economies of scale existed in the banking industry before the onset of the crisis and subsequent reforms in the '90s at all levels of output throughout the industry $[10,11]$. Consolidation in financial services in the USA and other industrialized countries has occurred along three lines, namely: within the banking industry, between banks and other non-bank financial institutions, and across national borders. In the USA, most of the consolidation that took place occurred within the banking sector. For instance, in that country, the number of banking organizations fell from about 12,000 in the early ' 80 s to about 7,000 in 1999, a decrease of over 40 per cent. In the USA and Canada, there has been a trend towards consolidation of commercial banks and investment or merchant banks, whereas in Europe, where the universal banking model is more prevalent, the trend has been to combine banking and insurance business. While most of the bank consolidations in the developed economies have occurred within the domestic front, there are signs of increased cross-border activities. Such cross-border activities have been facilitated in Europe with the launch of the Euro. The trend towards financial consolidation in Europe, USA and Asia could be traced to several factors. In the USA, one reason was the need to eliminate weak or problem financial institutions during the thrift and banking crisis of the late ' 80 s and early ' 90 s.

Some European countries experienced similar problems with institutions weakened by exposure to real estate lending. Advancement in telecommunication and information technology is another factor that has accelerated the pace of bank consolidation. This is due to the fact that this factor has radically reduced the cost of providing a host of financial services.

The lesson to be drawn from the bank consolidation in the advanced economies is that consolidation would result in fewer banking institutions and more branches. It could also be an active instrument of capital market development which could lead to financial sector stability. Apart from domestic M\&A's, consolidation could lead to increase in cross-border M\&A's which could facilitate the inflow of Foreign Direct Investment (FDI). Consolidation would certainly result in larger banks with implications for bank concentration and the "too big to fail" syndrome. 


\section{Strategies for Consolidation Adopted by Nigerian Banks}

A number of strategies were employed by banks in Nigeria in their bid to comply with the CBN minimum capital directive. The strategies are:

- Right issues for existing shareholders and capitalization of profits;

- Public offers through the capital market and/or private placement;

- Mergers and acquisitions; and

- A combination of the above strategies.

\section{Issues and Challenges Associated with the Consolidation}

The Nigerian banking system has undergone remarkable changes over the years, in terms of the number of institutions, ownership as well as depth and breadth of operations. These changes have been influenced largely by challenges posed by deregulation of the financial sector, globalization of operations, technological innovations and adoption of supervisory and prudential requirements that conform to international best practices. However, before attaining these fit, Kai [12] summarize the major problems that are still inherent in many banks in Nigeria as;

(a) Weak corporate governance, evidence by high turnover in the board and management staff, inaccurate reporting and noncompliance with regulatory requirements, falling ethics and de-marketing of other banks in the industry;

(b) Gross insider abuses, resulting in huge non-performing insider related credits;

(c) Over-dependence on public sector deposits, and neglect of small and medium class savers.

The issues and challenges confronting the consolidation process are examined under two headings, namely: pre-consolidation and postconsolidation.

Pre-Consolidation Issues; A number of issues were identified to be of critical importance in the pre-consolidation phase. Notable among these issues are:

1. Timeline given for the Consolidation Programme: Under normal condition, mergers and acquisitions take time to consummate because there are a number of processes which must be followed. However, giving the processes involved in consolidation, it is obvious that 18 months provided by SEC was inadequate for these processes to be effectively undertaken. Thus, what we have just witnessed in the Nigerian banking landscape are the mergers and acquisition of banks that were hastily packaged in order to beat the CBN deadline. Mergers and acquisitions are supposed to be voluntary strategies for consolidation. Therefore, the policy-induced M\&A's of banks in Nigeria suggests that the relevant institutions are likely to be faced with serious post-consolidation integration challenges.

2. High costs of Mergers and Acquisitions: The experience with the just concluded bank consolidation has shown that it is quite an expensive exercise. Most of the weak and marginal banks had to incur costs to go to the Capital Market to raise funds. They also had to bear the cost of mergers and acquisition. This involves the cost of preparing due diligence reports, cost of paying consultants, cost of preparing the Scheme document and other related costs. The issue of high cost of consolidation is not restricted to the weak banks, as the big and strong banks that acquired smaller banks had to bear similar and bigger costs.

3. Lack of Cooperation from Some of the Consolidating Banks: Ironically, some banks found it difficult to find a group to merge with or find a big bank to acquire them because, initially some of them were foot-dragging and some had refused to cooperate with the banks that showed interest in acquiring them as they continued to give difficult conditions with regard to some important issues, such as, the worth and the value of their shares, quality of their risk assets, number of representation on the board of the new bank and general lack of transparency in providing a timely information

4. Human Resource Issues: A lot of human resource related issues arise with regard to the consolidation programme. In the first instance, once two or more banks begin to talk about merger or acquisition, the staff of the affected institutions become jittery about job security which invariably affect their productivity. Certainly, consolidation might lead to job losses at the executive, general management, senior and junior staff cadres. For instance, it is not feasible to have two Managing Directors/Chief Executives in an organization. The second issue of concern is the variance level of compensation/remuneration packages of merging banks. In most cases, there exists a wide and unrealistic disparity in the remuneration packages of banks that have merged or have been acquired. This issue is more problematic in the case of a merger/acquisition between a big bank with a large workforce and smaller banks with small staff strength but high personnel cost.

5. Information and Communication Technology (ICT) Related Issues: It is a well-known fact that different banks employ different banking applications software to gain competitive edge. The challenge here is that some of these ICT packages are not compatible and banks have already incurred huge costs in the acquisition of these technologies. This, therefore, increases the cost of consolidation as the entire bank has to work under the coordination of one IT platform.

\section{Post-Consolidation challenges}

1. Corporate Governance: The status of corporate governance in the banking industry is expected to improve remarkably following the change in ownership structure. Thus, the dilution of ownership engendered by the new dispensation would ensure that a few individuals and their cronies do not have overbearing influence in the running and management of the banks unlike what used to happen in some privately owned banks where the influence of a few directors was very pronounced. However, the enlarged board membership that would result from consolidation could give rise to cleavages or "camps" that could result in boardroom squabbles. The leadership of the board should, therefore, be equipped to handle such division of opinion. Otherwise it could become a source of setback to the mega banks.

2. Post-Consolidation Integration: To merge or acquire an institution is one thing, but to get the institutions involved to work harmoniously is another. The post consolidation integration will pose more challenges in a consolidation case 
Citation: Dauda A (2013) An Eagle Eye View of Mergers and Acquisitions: A recipe for venture expansion. J Entrepren Organiz Manag 2: 102. doi:10.4172/2169-026X.1000102

Page 5 of 3

involving more than two institutions. The new organization may lack flexibility in responding quickly to changing market situation due to the large size. Additionally, every organization has its own corporate culture. When two or more organizations come together to form one company, there is bound to be culture conflicts. Such conflicts would be more where the style of management of the organizations differs. Thus, the integration of the operations, processes, procedures, people and products to let the consuming public see the emerging entity as one group is a daunting challenge which the consolidated banks have to contend with.

3. Challenge of Increased Returns on Investment: With the minimum capitalization of $\mathrm{N} 25$ billion for consolidated banks, the management of such banks is bound to operate under undue pressure from shareholders, who would be anxious to see higher returns on their investments. Currently, the average returns on invested capital (ROIC) in the Nigerian banking industry is estimated to be about $38 \%$. With the substantial increase in shareholders' funds engendered by the consolidation programme, each bank would need to generate an average minimum of $\mathrm{N} 9.5$ billion in profit before tax in order to maintain the same rate of return. Thus, the pressure that would mount on the management of the mega banks would force them to be more innovative and creative in coming up with new products and exploring other businesses, such as financing the real sector, which has hitherto been neglected. However, such pressure could also precipitate sharp and unethical practices by the banks if the regulatory environment is not tight.

\section{Type of Mergers}

From the perspective of business structure, the different type of merger is often distinguished by the relationship between the companies that are merging:

- Horizontal merger - it refers to two companies that are in direct competition and share the same product lines and markets.

- Vertical merger - it refers to a customer and company (forward integration) or a supplier and company (backward integration).

- Market-Extension merger - it refers to two companies that sell the same products in different market.

- Product-Extension merger - it refers to two companies selling different but related products in the same market.

- Conglomeration - here, it is two companies that have no common business areas.

- Reverse merger - it is a form of transaction that enables a private company to be publicly listed in a relatively short time frame. A reverse merger occurs when a privately held company (often one that has stronger prospects) buys a publicly listed shell company, usually one with little or no business and limited assets.

Indeed, economic history has been divided into merger waves based on the merger activities in the business world as shown below in table 1:

\section{The Deal process}

When top manager of a firm decide that they want to undergo a merger or acquisition, the process typically commence with the acquiring company filing an application with the security and exchange

\begin{tabular}{|c|c|c|}
\hline Period & Name & Facet \\
\hline $1897-1904$ & First wave & Horizontal merger \\
\hline $1916-1929$ & Second wave & $\begin{array}{r}\text { Vertical merger } \\
\hline 1965-1969\end{array}$ \\
\hline $1981-1989$ & Third wave & Diversified conglomerate merger \\
\hline $1992-2000$ & Fifth wave & $\begin{array}{r}\text { Concentric merger; hostile takeover; } \\
\text { corporate raiding }\end{array}$ \\
\hline $2003-2008$ & Sixth wave & Chass - border mergers \\
\hline
\end{tabular}

Source: adapted from Lamoreau [13]. The great merger movement in American business.

Table 1: Merger waves based on merger types.

commission (SEC). In the filing, the firm must formally declare the numbers of shares it owns and whether it intends to acquire the company or keep the shares purely as an investment, Foster [14].

In collaboration with financial advisors and investment bankers, the acquiring company will arrive at overall price that it is willing to pay for its target in cash, share or both of the company. The offer is then advertised publicly, stating the offer price and the deadline by which the shareholders/stakeholders in the target company must accept (or reject) it.

Once the offer has been made, the target company can take one of these several approaches:

(1) Accept the terms of the offer - if the target firms' shareholders and top managers are happy with the terms of the transaction, they will go ahead with the deal process.

(2) Attempt to negotiate - in this case, the offer price may not be reasonable enough for the target company's shareholders to accept, or the specific terms of the deal may not be very attractive. In a merger, there may be much at stake for the management team of the target company - their jobs in particular. If they are unsatisfied with the terms and conditions laid out in the offer, the target management may try to work out more agreeable terms that let them keep their jobs or, even better send them off with a big compensation package. In this regards, highly sought after target companies that are the object of several bidders will have greater latitude for negotiation. Furthermore, managers have more negotiating power if they can show that they are crucial to the merger's future success.

(3) Execute a poison pill as a hostile takeover defense - Here; a poison pill scheme can be triggered by a target company when a hostile suitor acquires a predetermined percentage of company shares. To execute its defense, the target company grants all shareholders - except the acquiring company options to buy additional stock at a deep discount. These tend to dilute the acquiring company's share and intercept its control of the company.

(4) Find a white knight - as an alternative to the hostile suitor, the target company's management may seek out a friendlier potential acquiring company, or white knight. If a white knight is found, it will offer an equal or higher price for the shares than the hostile bidder.

Finally, once the target company agrees to the tender offer and regulatory requirements are met; the merger deal is considered sealed to be executed. In a merger in which one company buys another, the acquiring company will pay for the target company's shares with stocks, cash or both. Cash for stock transaction is deemed fairly 
straight forward; target firms' shareholders receive a cash payment for each share purchased. When a company is purchased with stock, new shares from the acquiring company's stock are issued directly to the target company's management, or the new shares are sent to a broker who manages them for target company shareholders. When the deal is closed, investors usually get a new stock in the portfolios - the acquiring company's expanded stock.

Mergers and acquisitions often create brand problems one amongst is what to call the company after the transaction. Brand decisionmakers essentially can choose from four different approaches in dealing with company naming issues:

(a) Keep one name and discontinue the other: - the strongest legacy brand name with the best prospect for the future lives on. In the merger of united airlines and continental airlines, continental was retired for the former. Similarly, standard trust was retired in the union of United Bank for Africa (UBA) and standard trust bank (STB).

(b) Keep one name and demote the other: - in this case, the strongest name becomes the company name and the weaker one is demoted to a divisional brand or product brand. For instance, is caterpillar Inc. keeping the Bucyrus International name?

(c) Keep both names and use them together: - after a synergy, some companies try to please every party and keep the value of both brands by using them together. This can create an unwieldy name, as in the case of price water house-coopers, which has since change its brand name to "PwC" and that of platinum bank and Habib bank as platinum Habib Bank now Bank PHB in Nigeria.

(d) Discard both legacy names and adopt a totally new one. The typical example is the merger of Bell Atlantic with GTE, which became Verizon communications. Similarly, the union between Bank of the North and several other banks became known as Unity Bank

It is important to note that factors inducing brand decisions in a merger or acquisition transaction can range from tactical or political.

\section{Methodology of the study}

The study adopted a descriptive approach to analyze the viability of the Nigerian banks after the consolidation exercise.

\section{Results and Discussion}

According to the survey of recent development in the banking system, it revealed a significant reversal of dependence of many Nigerian banks on government deposits, with the three tiers of government and parastatals accounting for $30 \%$ of total deposit liabilities of deposit money in banks. Although the distribution among banks is not uniform, there are some banks whose dependency ratios are still high. The latest assessment shows that while the overall health of the Nigerian banking system could be described as generally satisfactory, the state of some are still volatile. The import of the above is that consolidation should be seen as journey rather than destination.

From table 2, it is obvious that the consolidation groupings followed four scenarios, namely:

- Some weak small and medium-sized banks that came together, e.g. Unity Bank and Skye Bank;

- Banks with regional or cultural affiliation and having common shareholders that came together, e.g. Intercontinental Bank Plc, Wema Bank Plc and Spring Bank Plc;

- Some large-size banks that acquired smaller and weaker ones in order to bail them out, e.g. the acquisition of UTB, Broad Bank and Union Merchant Bank Ltd. by Union Bank of Nigeria Plc;

- Large-sized banks and notable players in the industry that came together to form a bigger bank. The merger between UBA and STB is a classic example of this case.

From all indications, it appears that the preferred option by the $\mathrm{CBN}$ is for big and strong banks to acquire or merge with the smaller and weaker ones although the result of the consolidation did not show the adoption of much of this option.

Available statistics shows that during the 18-month consolidation period, the capital market received a boost with a total of $\mathrm{N} 406$ billion raised, out of which the apex bank has verified and cleared only N306 billion as at 31st December, 2005. The consolidation drive has also brought in a staggering $\$ 3$ billion into the sector, $\$ 500$ million of which represents FDI. This is the highest inflow of FDI into the non-oil sector within one year.

The table below shows the names of the 25 banks that successfully met the $\mathrm{N} 25$ billion minimum share capital requirement and the banks that constitute each group.

The Table 2 reveals the top 10 M\&A deals world over by value between 2000-2008.

As earlier mentioned, a merger wave in Merger \&Acquisition was experienced in Nigeria following the consolidation and recapitalization

\begin{tabular}{|c|c|c|c|}
\hline Ranks & Year & Purchaser & Purchased \\
\hline 1 & 2000 & Fusion: America online inc. (AOL) & Time Warner \\
\hline 2 & 2000 & Glaxo Welcome PLC & SmithKline Beecham PLC \\
\hline 3 & 2004 & Royal Dutch Petroleum Co. & Shell Transport and Trading Co. \\
\hline 4 & 2006 & AT \& T Inc & BellSouth Corporation \\
\hline 5 & 2001 & Comcast Corporation & 74,559 \\
\hline 6 & 2009 & Pfizer Inc. & AT \& T Broad Band and Internet Services \\
\hline 7 & 2000 & Spin-off: Nortel Networks corporation & Wyeth \\
\hline 8 & 2002 & Pfizer Inc. & Pharmacia corporation \\
\hline 9 & 2004 & JP Morgan Chase \& Co. & Bank one corp. \\
\hline 10 & 2008 & Inbey Inc. & 59,974 \\
\hline
\end{tabular}

Source: Adopted from Lamoreau [13]. The great Merger Movement in American Business

Table 2: Top 10 M\&A deals worldwide by value (in mil USD) from 2000- 2008. 
Citation: Dauda A (2013) An Eagle Eye View of Mergers and Acquisitions: A recipe for venture expansion. J Entrepren Organiz Manag 2: 102. doi:10.4172/2169-026X.1000102

Page 7 of 3

\begin{tabular}{|c|c|}
\hline New Banks & Old Banks \\
\hline Access Bank & Access Bank Nigeria Plc + Marina Intercontinental + Capital Bank Intercontinental Ltd \\
\hline Afribank & Afribank Nigeria Plc + Afribank Intercontinental Ltd \\
\hline BankPHB & Platinum + Habib Bank - owns majority stake in Spring Bank \\
\hline ETB-Equitorial Trust Bank & Equitorial Trust Bank Limited + Devcom Bank Ltd \\
\hline Diamond Bank & Diamond Bank Ltd + Lion Bank of Nigeria Plc \\
\hline FCMB & FCMB + MBC intercontinental Bank PIc + FBN Merchant Bankers Limited \\
\hline Fidelity Bank & Acquired FSB Intercontinental \\
\hline First Bank & First Bank of Nigeria PLC + MBC intercontinental Bank PIc + FBN Merchant Bankers Limited) \\
\hline First Inland Bank & First Atlantic Bank Plc + Inland Bank \\
\hline Stanbic-IBTC & Stanbic Bank Nigeria Plc + IBTC Chartered Bank Plc \\
\hline Intercontinental Bank & Intercontinental bank Ltd + Equity Bank of Nig Ltd + Global Bank Plc + Gateway Bank Plc. \\
\hline Skye Bank & Prudent Bank Plc + EIB intercontinental Bank Plc + Bond Bank + Reliance Bank \\
\hline Spring Bank & $\begin{array}{c}\text { ACB intercontinental Bank Plc + Citizens International Bank Plc + Fountain Trust Bank Plc + Guardian Express Bank Plc + Omega Bank } \\
\text { Plc + Trans International Bank }\end{array}$ \\
\hline Sterling Bank & Trust Bank of Africa + Magnum Trust Bank + NBM Bank + NAL Bank Plc + Indo Nigeria Bank \\
\hline United Bank for Africa & Standard Trust Bank + UBA \\
\hline Unity Bank & $\begin{array}{c}\text { Bank of the North Ltd + NNB International Bank Plc + New Africa Bank Ltd + Intercity Bank Plc + First Interstate Merchant Bank Ltd + } \\
\text { Tropical commercial Bank Plc + Pacific Bank Ltd + Center Point Merchant Bank Ltd + Societe Bancaire Nigeria Ltd. }\end{array}$ \\
\hline Wema Bank & Wema Bank + National Bank + Fortune Bank + Lead Bank \\
\hline
\end{tabular}

Source: CBN statistical bulletin, various issues (2006- 2010)

Table 3: Merger \& Acquisition involving Nigerian Banks.

exercise in the banking industry which saw the number of banks drop from 89 to 25

The Table 3 reveals a list of banks which were involved in $\mathrm{M} \& \mathrm{~A}$ in compliance with the CBN directive for Bank consolidation.

\section{Conclusion}

In this paper, an attempt was made to critically review the issues and challenges associated with banking sector consolidation programme in Nigeria. Although the programme has been concluded with twenty-five banks meeting the consolidation timeline, the banks should brace up for the imminent post-consolidation integration challenges. There is no doubt that the banking sector consolidation programme is the right step to take by the CBN as it is capable of engendering healthy competition among banks and making banks to be more creative and innovative. It also has the potential of accelerating the rate of economic growth and development of the country. However, to ensure that the synergy it envisage is fully harnessed, and to mitigate post-consolidation conflicts, adequate steps should be taken to train and retrain the staff of all the banks that have scaled the capitalization huddle while the regulatory environment has to be tightened to close all the loopholes that could come up as a result of the increased size of the firms in the industry. In that regard, they should enhance their risk management capacity, enthrone responsive corporate governance, embrace the right culture that would promote market discipline and should complement statutory regulation with self-regulation and self-discipline. The Regulatory/ Supervisory Authorities should be more proactive in the discharge of their role with implications for capacity building in all relevant areas.

\section{References}

1. Adam JA (2005) Banking Sector Reforms: The Policy Challenges of Bank Consolidation in Nigeria, Nigerian Economic Society (NES) Annual Conference, Lagos. $23^{\text {rd }}-25^{\text {th }}$ August.

2. Nnanna OJ (2004) Beyond Bank Consolidation: The Impact of Society" Monetary Policy Conference, Central Bank of Nigeria. Abuja, $18^{\text {th }}-19^{\text {th }}$ November.

3. Imala OI (2005) Consolidation in the Nigerian Banking Industry: A Strategy for Survival and Development, Nigerian Economics Students' Association (NESA), University of Abuja.
4. Lemo T (2005) Regulatory Oversight and Stakeholder Protection. A Paper Presented at the BGL Mergers and Acquisitions Interactive Seminar, Eko Hotels \& Suits. Volume 1

5. Maddigan RJ, Janis KZ (2005) The profitability of vertical integration. Managerial and Decision economics 6: 178-179.

6. Uwaleke U (2011) Managerial finance. Abuja: Onaivi press.

7. Hall MJB (1999) Japan's Big Bang: The Likely Winners and Losers. Journal of International Banking Law 7: 204-16.

8. Kwan S (2004) Banking Consolidation: Federal Reserve Bank of San Francisco (FRBSF) Economic Letter, USA.

9. Akhavin JD, Berger AN, Humphrey B et al. (1997) The Effects of Megamergers on Efficiency and Prices: Evidence from a Bank Profit Function. Review of Industrial Organization 12: 95-135.

10. Fukuyama H (1993) Technical and Scale Efficiency in Japanese Commercia Banks: A non-Parametric Approach, Applied Economics 25: 1101-1112.

11. McKillop DG, Glass JC, Morikawa Y et al. (1996) The Composite Cost Function and Efficiency in Giant Japanese Banks, Journal of Banking and Finance 20: 1651-1671.

12. Kai Lucks, (2002). International Merger \& Acquisition. Springer DE, Germany.

13. Lamoreaux R (2009) The great merger movement in American business Cambridge University press, UK.

14. Foster RS (2004) The Classic Merger \& Acquisition Handbook. The art of M\&A A Merger \& Acquisitions Buyout (3rd edn). McGraw-Hill, USA 